\title{
Pengaruh Dimensi Gambar Pada Data Training Terhadap Prediksi Kepribadian Menggunakan Convolutional Neural Network
}

\author{
Chan Uswatun Khasanah ${ }^{1)}$, Ema Utami ${ }^{2}$, Hanif Al Fatta ${ }^{3)}$ \\ 1,2,3 Universitas AMIKOM Yogyakarta \\ 1,2,3 Jl. Ring Road Utara, Condong Catur, Sleman 55283 Indonesia \\ 1'chan8160@students.amikom.ac.id, ${ }^{2}$ emma@nrar.net, ${ }^{3}$ hanif.a@amikom.ac.id
}

\begin{abstract}
Abstrak
Foto atau gambar yang diposting di Instagram dapat menunjukkan kepribadian penggunanya. Convolutional Neural Network (CNN) memiliki tingkat akurasi yang tinggi dalam memprediksi kepribadian dari sumber data gambar. Tujuan penelitian ini adalah untuk mengetahui apakah dimensi gambar pada data training berpengaruh terhadap prediksi kepribadian berdasarkan gambar yang diposting di Instagram menggunakan CNN. Dataset yang digunakan berupa gambar yang terdiri dari 376 data training dan 93 data testing. Data training bersumber dari Instagram dan Google Image dengan jenis gambar yang sama namun dimensi gambar yang berbeda. Penelitian ini akan melakukan perbandingan proses training dengan gambar yang bersumber dari Instagram dan Google Image. Hasil penelitian yang didapatkan adalah tingkat akurasi pada proses training dengan data yang bersumber dari Instagram dan Google Image adalah 100\% dan 99,6\% dengan waktu training yang lebih lama pada sumber data Google Image. Pengujian dilakukan dengan menginputkan 93 gambar ke arsitektur CNN yang telah dibuat. Hasil pengujian adalah sebanyak 93 gambar diprediksi benar sebagai kepribadian Agreeableness dengan data training bersumber dari Instagram dan 92 gambar diprediksi benar dengan data training bersumber dari Google Image. Kesimpulan yang didapatkan adalah dimensi gambar pada data training tidak berpengaruh secara signifikan terhadap prediksi kepribadian berdasarkan gambar yang diposting di Instagram.
\end{abstract}

Kata kunci:Prediksi kepribadian, CNN, dimensi gambar, data training, data testing.

\section{PENDAHULUAN}

"Gambar mewakili 1000 kata", ungkapan tersebut benar adanya. Bahkan dengan munculnya media sosial telah merubah peran gambar yang awalnya hanya sebagai objek yang dapat menyampaikan informasi secara visual, namun gambar juga dapat menjadi sesuatu yang personal, yang dapat mewakili diri mereka sendiri dan memiliki karakteristik individual, seperti sifat kepribadian.

Salah satu media sosial populer yang memungkinkan pengguna untuk berbagi foto atau gambar adalah Instagram. Melalui gambar, pengguna Instagram dapat berbagi aktivitas mereka sehari-hari dan mengekspresikan diri melalui gambar yang mereka posting. Bahkan, gambar yang diposting di Instagram diketahui lebih prediktif dalam memprediksi kepribadian dibandingkan gambar profil serta gambar yang disukai di Twitter dan Flickr (Samani, Guntuku, Moghaddam, Preoţiuc-Pietro, \& Ungar, 2018).
Berdasarkan penelitian yang telah dilakukan sebelumnya (Schmitt et al., 2007), kepribadian big five telah terbukti konsisten untuk diterapkan di berbagai usia, jenis kelamin, bahasa, dan budaya. Model ini membedakan kepribadian manusia menjadi lima dimensi yang biasa juga disebut dengan OCEAN, yaitu Openness $(\mathrm{O})$ untuk mengukur tingkat penyesuaian, Conscientiousness (C) untuk mengukur tingkat kehati-hatian, Extraversion (E) untuk mengukur tingkat keterbukaan, Agreeableness (A) untuk mengukur tingkat keramahan, dan Neuroticism (N) untuk mengukur tingkat kecemasan.

Computer vision dengan Convolutional Neural Network (CNN) telah mendapatkan banyak perhatian dalam beberapa tahun terakhir karena sangat cocok untuk memproses data dalam jumlah yang besar dan memberikan kinerja yang luar biasa terhadap objek dan gaya gambar. Sejak diadakannnya Imagenet Large Scale Visual Recognition Challenge (ILSVRC), perkembangan CNN 
semakin pesat (Russakovsky et al., 2015). ILSVRC adalah suatu kompetisi tahunan yang melombakan klasifikasi basis data gambar yang ada pada Imagenet yang memiliki 1000 kelas dan setiap tahunnya "melahirkan" berbagai macam arsitektur CNN. CNN memiliki kemampuan untuk mendeteksi dan mengenali objek pada sebuah gambar. Beberapa penelitian yang telah dilakukan, $\mathrm{CNN}$ memiliki tingkat akurasi yang tinggi dalam memprediksi kepribadian (Guntuku et al., 2017) (Segalin, Celli, et al., 2017).

Gambar yang berasal dari postingan Instagram memiliki dimensi dengan nilai maksimal width dan height adalah $1080 \mathrm{px}$ dengan resolusi 96 dpi. Namun berbeda dengan gambar yang diperoleh dari sumber lain, seperti Google Image, yang dapat memiliki nilai width dan height yang berbedabeda serta resolusi yang beragam.

Gambar 1 menunjukkan perubahan yang terjadi pada gambar setelah diposting di Instagram. Pada mulanya dimensi gambar adalah 1079 x 1500 px dengan resolusi 100 dpi. Setelah diposting di Instagram, dimensi gambar berubah menjadi 1080 x 1080 px dengan resolusi 96 dpi. Terlihat bagian atas dan bawah gambar terpotong sebagian.
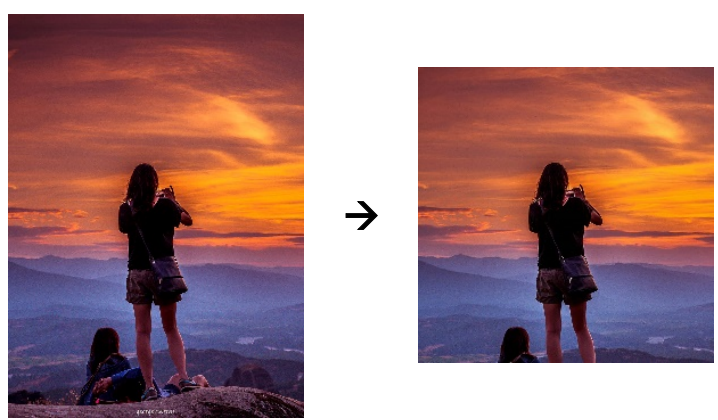

Gambar 1. Perubahan Gambar Setelah Diposting di Instagram

Rumusan masalah dari penelitian ini adalah "Apakah dimensi gambar pada data training berpengaruh terhadap prediksi kepribadian big five berdasarkan gambar yang diposting di Instagram menggunakan CNN?"

Tujuan dari penelitian yang dilakukan adalah untuk mengetahui pengaruh dimensi gambar pada data training dalam melakukan prediksi kepribadian big five berdasarkan gambar yang diposting di Instagram menggunakan Convolutional Neural Network. Jika dimensi gambar (width, height, resolusi) pada data training tidak berpengaruh terhadap prediksi kepribadian maka data training dapat berasal dari sumber manapun dengan dimensi gambar yang beragam. Namun, jika dimensi gambar pada data training berpengaruh terhadap prediksi kepribadian maka data training harus berasal dari Instagram dengan dimensi gambar yang relatif sama.

\section{METODE PENELITIAN}

\section{a. Alat dan Bahan}

Penelitian ini menggunakan laptop dengan spesifikasi RAM 5 GB dan VGA Intel HD Graphic 3000.

Dalam melakukan pemrosesan data, penelitian ini menggunakan bahasa pemrograman Python dengan framework Tensorflow dan library Keras. Untuk melakukan visualisasi terhadap proses training, peneliti menggunakan Tensorboard.

\section{b. Alur Penelitian}

Alur dalam penelitian ini adalah sebagai berikut.

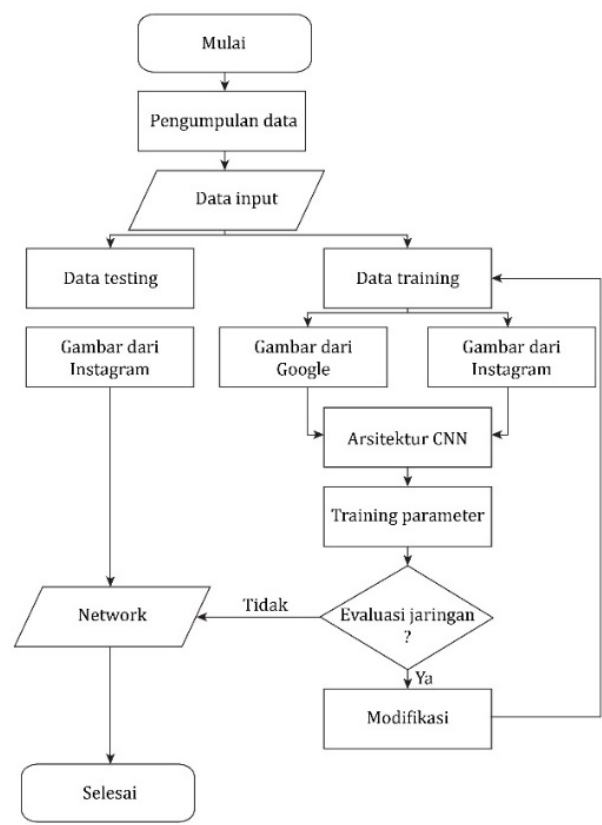

Gambar 2. Alur Penelitian

Penelitian diawali dengan melakukan pengumpulan data berupa gambar. Data input terbagi menjadi dua, yaitu data training dan data testing. Data training berasal dari sumber yang berbeda, yaitu Instagram dan Google Image, namun dengan jenis gambar yang sama yang akan digunakan untuk melatih arsitektur CNN yang dibuat. Jika hasil training menunjukkan akurasi yang baik, maka model CNN akan diuji dengan data 
testing untuk mengetahui berapa banyak gambar yang diprediksi dengan benar. Perbandingan jumlah data training dan data testing adalah 80:20.

\section{c. Metode Pengumpulan Data}

Data input yang digunakan terdiri dari gambar-gambar yang diperoleh dari Google Image dengan teknik crawling. Karena tujuan penelitian ini untuk mengetahui pengaruh dimensi gambar pada data training terhadap prediksi kepribadian, maka cukup dua kepribadian saja yang digunakan, yaitu Agreeableness dan Neuroticism.

Keyword yang digunakan untuk melakukan crawling di Google Image adalah "evening" untuk kepribadian Agreeableness dan "mountain" untuk kepribadian Neuroticism. Keyword tersebut berdasarkan penelitian yang dilakukan oleh (Yarkoni, 2010). Penelitian tersebut menghasilkan berbagai macam kata-kata yang berhubungan dengan kepribadian big five.

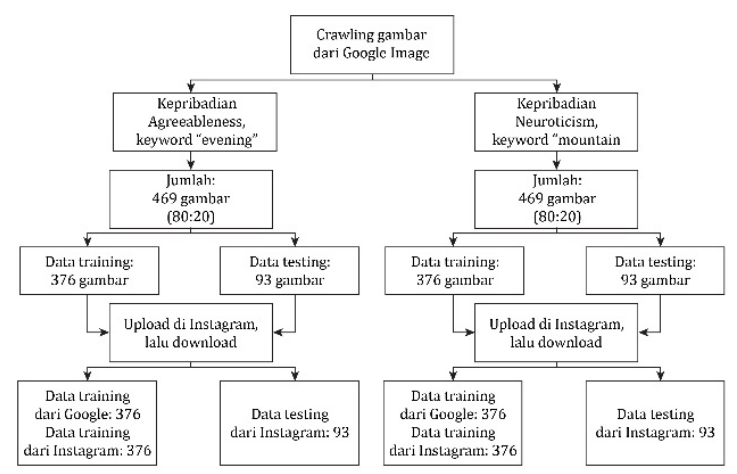

Gambar 3. Metode Pengumpulan Data

Data yang terkumpul dari proses crawling adalah 469 gambar untuk masingmasing kepribadian dengan keyword "evening" dan "mountain". Jumlah keseluruhan adalah 938 gambar. Untuk mendapatkan jenis gambar yang sama namun dengan sumber yang berbeda, seluruh gambar diposting di akun Instagram peneliti kemudian gambar tersebut didownload dengan menggunakan fitur download data. Jadi, data terbagi menjadi 2 sumber, yaitu Instagram dan Google Image.

Data testing merupakan gambar yang bersumber dari Instagram. Terdapat dua skenario dalam melakukan penelitian ini. Skenario pertama adalah menggunakan data training yang bersumber dari Instagram kemudian diuji menggunakan data testing.
Skenario kedua adalah menggunakan data training yang bersumber dari Google Image kemudian diuji menggunakan data testing. Jumlah data yang digunakan pada masingmasing kepribadian adalah 376 gambar untuk data training dan 93 gambar untuk data testing.

\section{d. Arsitektur CNN}

Arsitektur CNN pada penelitian ini terdiri dari lapisan input, 2 lapisan konvolusi, 1 lapisan flattten/fully connected, dan lapisan output.

Tabel 1. Arsitektur CNN

\begin{tabular}{lc}
\multicolumn{1}{c}{ Lapisan } & Size \\
\hline Input & $64 \times 64 \times 3$ \\
Conv1 & $3 \times 3 \times 32$ \\
Max Pool1 & $2 \times 2$ \\
Conv2 & $3 \times 3 \times 32$ \\
Max Pool2 & $2 \times 2$ \\
Flatten & - \\
Dense & 128 \\
Output & $64 \times 64 \times 3$ \\
\hline
\end{tabular}

Pada lapisan input, data yang digunakan adalah data training. Kemudian data input diproses pada lapisan konvolusi pertama menggunakan max pooling dan fungsi aktivasi ReLU. Output pada lapisan konvolusi pertama dijadikan sebagai input pada proses konvolusi kedua. Hasil dari proses konvolusi dikumpulkan pada lapisan flatten atau fully connected.

\section{TINJAUAN PUSTAKA}

Penelitian yang berkaitan dengan kepribadian di berbagai macam domain kini sudah banyak dilakukan. Bahkan informasiinformasi yang berasal dari media sosial pun dapat secara langsung relevan dengan sifat kepribadian pengguna, seperti penelitian yang telah dilakukan oleh (Ferwerda \& Tkalcic, 2018) pada Instagram, (Segalin, Cheng, \& Cristani, 2017) pada Facebook dan Flickr, dan (Guntuku et al., 2017) pada Twitter. Bahkan, gambar yang diposting di Instagram diketahui dapat lebih prediktif dalam memprediksi kepribadian dibandingkan gambar profil serta gambar yang disukai di Twitter dan Flickr (Samani et al., 2018).

(Rodriguez, Gonzàlez, Gonfaus, \& Roca, 2019) dalam penelitiannya melakukan prediksi kepribadian big five berdasarkan 
gambar yang diposting di Instagram dengan menggunakan dataset MindPics. Untuk membangun MindPics, peneliti mengumpulkan gambar yang ada di Instagram menggunakan API Instagram. Masing-masing kepribadian terdiri dari kurang lebih 24.000 gambar sehingga terkumpul 121.000 gambar untuk lima kepribadian. Arsitektur CNN yang digunakan adalah AlexNet dan ResNet.

(Segalin, Cheng, et al., 2017) dalam penelitiannya melakukan prediksi kepribadian big five berdasarkan gambar yang diposting di Flickr. Untuk melatih CNN, peneliti menggunakan dataset Psychoflickr yang terdiri dari 60.000 gambar favorit/disukai yang berasal dari Flickr.

Dapat disimpulkan bahwa penelitianpenelitian sebelumnya menggunakan dataset yang berasal dari media sosial yang digunakan sebagai objek penelitian, seperti prediksi kepribadian berdasarkan gambar yang diposting di Instagram maka dataset yang digunakan berasal dari Instagram dan prediksi kepribadian berdasarkan gambar favorit/disukai di Flickr maka dataset yang digunakan berasal dari Flickr.

Penelitian ini akan membahas apakah dataset yang digunakan sebagai data training dalam memprediksi kepribadian berdasarkan gambar yang diposting di Instagram dapat dilakukan dari sumber yang berbeda yang memiliki dimensi gambar bermacam-macam.

\section{HASIL DAN PEMBAHASAN}

Hasil dan pembahasan terbagi menjadi dua proses, yaitu pada saat melakukan pelatihan (training) dan pengujian (testing).

\section{a. Pelatihan (Training)}

Proses training menggunakan arsitektur CNN yang telah dibangun dengan dataset yang berasal dari dua sumber, yaitu Instagram dan Google Image.

\section{1) Data Training dari Instagram}

Dalam melakukan pelatihan pada data training yang bersumber dari Instagram, epochs yang digunakan berjumlah 25 dengan batch size 10.

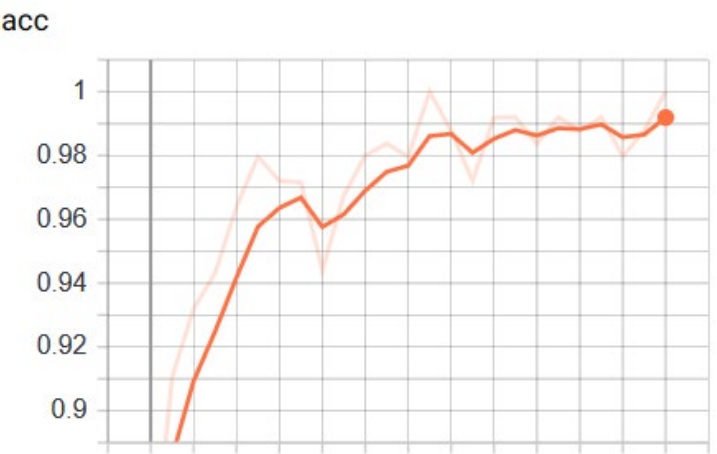

Gambar 4. Training Accuracy dengan Data Training dari Instagram

loss

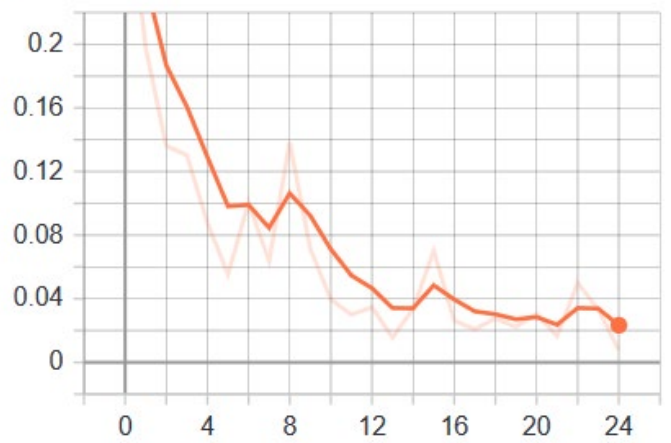

Gambar 5. Training Loss dengan Data

Training dari Instagram

Berdasarkan Gambar 4 dan 5, dapat diketahui bahwa nilai akurasi mengalami peningkatan dan nilai loss mengalami penurunan.

\section{2) Data Training dari Google Image}

Dalam melakukan pelatihan pada data training yang bersumber dari Google Image, epochs yang digunakan berjumlah 25 dengan batch size 10.

acc

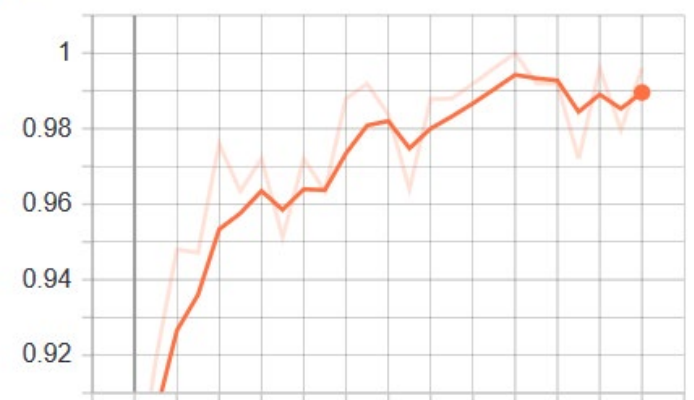

Gambar 6. Training Accuracy dengan Data Training dari Google Image 
loss

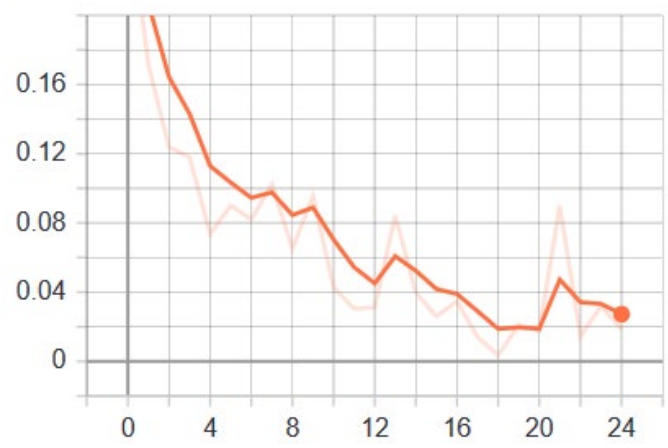

Gambar 7. Training Loss dengan Data

Training dari Google Image

Berdasarkan Gambar 6 dan 7, dapat diketahui bahwa nilai akurasi mengalami peningkatan dan nilai loss mengalami penurunan.

\section{b. Pengujian (Testing)}

Pengujian yang dilakukan hanya berfokus pada kepribadian Agreeableness. Data testing yang digunakan berjumlah 93 gambar yang menunjukkan kepribadian Agreeableness. Data testing diuji dengan 2 skenario. Skenario pertama menggunakan data training yang bersumber dari Instagram sedangkan skenario kedua menggunakan data training yang bersumber dari Google Image. Hasil dari pengujian yang dilakukan dengan skenario pertama dan kedua adalah sebanyak 93 gambar dan 92 gambar yang berhasil diprediksi sebagai kepribadian Agreeableness. Ringkasan dari hasil proses pelatihan hingga pengujian ditunjukkan pada Tabel 2.

Tabel 2. Hasil Proses Training dan Testing

\begin{tabular}{|c|c|c|c|c|c|c|}
\hline \multirow[b]{2}{*}{$\begin{array}{c}\text { Datase } \\
t\end{array}$} & \multirow[b]{2}{*}{$\begin{array}{c}\text { Sumber } \\
\text { Data }\end{array}$} & \multirow[b]{2}{*}{$\begin{array}{l}\text { Jumla } \\
\text { h Data }\end{array}$} & \multirow[b]{2}{*}{$\begin{array}{l}A c c \\
(\%)\end{array}$} & \multicolumn{2}{|c|}{ Prediksi Benar } & \multirow[b]{2}{*}{$\begin{array}{c}\text { Kecepata } \\
\text { n } \\
\text { Training }\end{array}$} \\
\hline & & & & $\begin{array}{c}\text { Sumb } \\
\text { er } \\
\text { Data } \\
\text { Traini } \\
\text { ng } \\
\text { dari } \\
\text { Instag } \\
\text { ram }\end{array}$ & $\begin{array}{c}\text { Su } \\
\text { mb } \\
\text { er } \\
\text { Dat } \\
\text { a } \\
\text { Tra } \\
\text { inin } \\
g \\
\text { dar } \\
\text { i } \\
\text { Go } \\
\text { ogle } \\
\text { Ima } \\
\text { ge }\end{array}$ & \\
\hline \multirow{2}{*}{$\begin{array}{l}\text { Data } \\
\text { trainin } \\
g\end{array}$} & Instagram & 376 & 100 & & & $\begin{array}{c}896 \\
\mathrm{~ms} / \text { step }\end{array}$ \\
\hline & $\begin{array}{l}\text { Google } \\
\text { Image }\end{array}$ & 376 & 99,6 & & & $2 \mathrm{~s} / \mathrm{step}$ \\
\hline $\begin{array}{l}\text { Data } \\
\text { testing }\end{array}$ & Instagram & 93 & & 93 & 92 & \\
\hline
\end{tabular}

\section{KESIMPULAN DAN SARAN}

a. Kesimpulan

Berdasarkan penelitian yang telah dilakukan, diketahui bahwa selisih antara nilai akurasi pada data training yang bersumber dari Google Image adalah 0,4\% lebih rendah daripada menggunakan data training yang bersumber dari Instagram. Dapat disimpulkan bahwa nilai akurasi dalam proses training dengan CNN dapat meningkat apabila data training memiliki dimensi gambar yang relatif sama.

Hasil dari pengujian (testing) menggunakan data training yang bersumber dari Instagram menunjukkan gambar dengan prediksi benar berjumlah 93, artinya semua data testing berhasil diprediksi dengan benar. Sedangkan data training yang bersumber dari Google Image menunjukkan gambar dengan prediksi benar berjumlah 92, artinya hanya ada 1 gambar yang diprediksi dengan salah. Dapat disimpulkan bahwa pengujian mendapatkan hasil yang tinggi meskipun training yang dilakukan menggunakan data training dengan dimensi gambar yang beragam.

Semakin besar dimensi gambar (width, height, resolusi) pada data training maka waktu yang dibutuhkan dalam proses training pun semakin lama. Sebaliknya, semakin kecil dimensi gambar pada data training maka proses training akan semakin cepat.

\section{b. Saran}

Penelitian selanjutnya diharapkan dapat menerapkan bagaimana cara memprediksi kepribadian big five berdasarkan gambar yang diposting di Instagram sehingga persentase nilai masing-masing kepribadian big five dapat diketahui.

\section{REFERENSI}

Ferwerda, B., \& Tkalcic, M. (2018). Predicting Users' Personality from Instagram Pictures (pp. 157-161).

Guntuku, S. C., Lin, W., Carpenter, J., Ng, W. K., Ungar, L. H., \& Preoţiuc-Pietro, D. (2017). Studying Personality through the Content of Posted and Liked Images on Twitter, 223-227.

Rodriguez, P., Gonzàlez, J., Gonfaus, J. M., \& Roca, F. X. (2019). Integrating Vision and Language in Social Networks for Identifying Visual Patterns of 
Personality Traits, $9(1)$.

Russakovsky, O., Deng, J., Su, H., Krause, J., Satheesh, S., Ma, S., Huang, Z., et al. (2015). ImageNet Large Scale Visual Recognition Challenge. International Journal of Computer Vision, 115(3), 211-252. Springer US. Retrieved from http://dx.doi.org/10.1007/s11263-0150816-y

Samani, Z. R., Guntuku, S. C., Moghaddam, M. E., Preoţiuc-Pietro, D., \& Ungar, L. H. (2018). Cross-platform and crossinteraction study of user personality based on images on Twitter and Flickr. PLoS ONE, 13(7), 1-19.

Schmitt, D. P., Allik, J., McCrae, R. R., Benet-Martínez, V., Alcalay, L., Ault, L., Austers, I., et al. (2007). The geographic distribution of Big Five personality traits: Patterns and profiles of human self-description across 56 nations. Journal of Cross-Cultural Psychology, 38(2), 173-212.

Segalin, C., Celli, F., Polonio, L., Kosinski, M., Stillwell, D., Sebe, N., Cristani, M., et al. (2017). What your Facebook Profile Picture Reveals about your Personality, 460-468.

Segalin, C., Cheng, D. S., \& Cristani, M. (2017). Social profiling through image understanding: Personality inference using convolutional neural networks. Computer Vision and Image Understanding, 156, 34-50. Elsevier Inc. Retrieved from http://dx.doi.org/10.1016/j.cviu.2016.10. 013

Yarkoni, T. (2010). Personality in 100,000 Words: A large-scale analysis of personality and word use among bloggers. Journal of Research in Personality, 44(3), 363-373. Elsevier Inc. Retrieved from http://dx.doi.org/10.1016/j.jrp.2010.04.0 01 